\title{
Regulation by Glucose of Oscillatory Electrical Activity and 5-HT/Insulin Release from Single Mouse Pancreatic Islets in Absence of Functional $\mathrm{K}_{\mathrm{ATP}}$ Channels
}

\author{
Luís M. ROSÁRIO*,**, RUI M. BARBOSA*,***, CéLIA M. ANTUNES*,\#, INêS E. BALDEIRAS\#\#, \\ AMélia M. SILVA \#\#\#,b, ÂNGELO R. TOMÉ*,** AND RosA M. SANTOS*,** \\ *Center for Neurosciences and Cell Biology, University of Coimbra, Coimbra, Portugal \\ **Department of Biochemistry, Faculty of Sciences and Technology, University of Coimbra, Coimbra, Portugal \\ ***Laboratory of Instrumentation and Analysis, Faculty of Pharmacy, University of Coimbra, Coimbra, Portugal \\ \#Chemistry Department, University of Évora, Évora, Portugal \\ \#Laboratory of Neurochemistry, Neurology Service, Coimbra University Hospital, Coimbra, Portugal

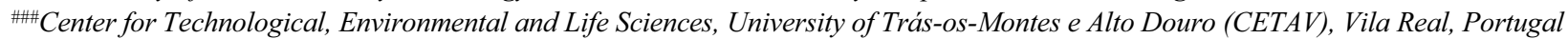 \\ ${ }^{b}$ Department of Biological and Environmental Engineering, University of Trás-os-Montes e Alto Douro (UTAD), Vila Real, Portugal
}

\begin{abstract}
The glucose sensitivity of bursting electrical activity and pulsatile insulin release from pancreatic islets was determined in absence of functional $\mathrm{K}_{\mathrm{ATP}}$ channels. Membrane potential, $\left[\mathrm{Ca}^{2+}\right]_{\mathrm{i}}$ and 5-HT/insulin release were measured by intracellular recording, fura-2 fluorescence and 5-HT amperometry, respectively. Single mouse islets, bathed in tolbutamide or glibenclamide and high extracellular $\mathrm{Ca}^{2+}\left(\mathrm{Ca}^{2+}{ }_{\mathrm{o}}\right)$, displayed bursting activity and concomitant fast $\left[\mathrm{Ca}^{2+}\right]_{\mathrm{i}}$ and 5-HT/insulin oscillations. Sulphonylurea block of $\mathrm{K}_{\mathrm{ATP}}$ channel current was unaffected by raising $\mathrm{Ca}^{2+}{ }_{0}$. Raising glucose or $\alpha$-ketoisocaproic acid (KIC) concentration from 3 to $30 \mathrm{mM}$ increased spiking activity and burst plateau duration. Staurosporine did not impair glucose potentiation of electrical activity, ruling out the involvement of serine/ threonine kinases. Glucose enhanced both $\left[\mathrm{Ca}^{2+}\right]_{\mathrm{i}}$ and 5-HT/insulin oscillatory activity, causing a $\sim 3$-fold increase in overall 5-HT release rate. Cells lacking bursting activity in high $\mathrm{Ca}^{2+}{ }_{\mathrm{o}}$ and low glucose (or KIC) developed a pattern of intensified spiking in response to $11 \mathrm{mM}$ glucose. It is concluded that $\beta$-cells exhibit graded oscillatory electrical and secretory responses to glucose in absence of functional $\mathrm{K}_{\mathrm{ATP}}$ channels. This suggests that, under physiological conditions, early glucose sensing may involve other channels besides the $\mathrm{K}_{\mathrm{ATP}}$ channel.
\end{abstract}

Key words: Pancreatic $\beta$-cells, bursting electrical activity, ATP-sensitive $\mathrm{K}^{+}$channels, pulsatile insulin release

(Endocrine Journal 55: 639-650, 2008)

PANCREATIC $\beta$-cells secrete insulin in response to glucose and, thus, play a pivotal role in glucose homeostasis. The initial triggering events are relatively well understood. The ATP-sensitive $\mathrm{K}^{+}\left(\mathrm{K}_{\text {ATP }}\right)$ channel, in particular, represents a crucial link between glucose metabolism and $\mathrm{Ca}^{2+}$ entry. Increasing glucose concentration raises the cytosolic ATP/ADP ratio, closing $\mathrm{K}_{\text {ATP }}$ channels and evoking the depolarization required to initiate electrical activity [1]. Employing

Received: November 26, 2007

Accepted: March 5, 2008

Correspondence to: Luís M. ROSÁRIO, Department of Biochemistry, FCTUC, P.O. Box 3126, 3001-401 Coimbra, Portugal intracellular $\mathrm{Ca}^{2+}$ clamping techniques, an amplifying pathway (also known as $\mathrm{K}_{\mathrm{ATP}}$ channel-independent pathway) for $\mathrm{Ca}^{2+}$-dependent insulin release has been uncovered $[2,3]$ whose mediators remain elusive $[4,5]$.

$\beta$-Cells undergo cyclic changes in membrane potential, with $\mathrm{Ca}^{2+}$-dependent action potentials superimposed on the depolarized plateaus, the duration of which increases as glucose concentration is raised above threshold ( $\sim 6-7 \mathrm{mM})$. Bursting electrical activity is matched by prominent fast oscillations of cytosolic free $\mathrm{Ca}^{2+}$ concentration $\left(\left[\mathrm{Ca}^{2+}\right]_{\mathrm{i}}\right)$ and insulin release (or insulin tracers such as 5-HT), measured at the single islet level [6-8]. Bursting electrical activity has also been recorded in vivo [9], suggesting that oscilla- 
tory insulin output from individual islets might be a fundamental determinant of plasma insulin pulsatility in spite of considerable frequency differences $[8,10]$.

Stimulating islet $\beta$-cells with a voltage clamp command designed to mimic an islet burst activates a slowly developing $\mathrm{K}^{+}$current $\left(\mathrm{I}_{\mathrm{K} \text {,slow }}\right)$ by a $\mathrm{Ca}^{2+}$-dependent mechanism [11, 12]. Whether $\mathrm{K}_{\mathrm{ATP}}$ channels might contribute to $I_{K, \text { slow }}$ is currently uncertain. Some authors [13] reported a tolbutamide-sensitive component of $I_{K, \text { slow }}$ which, however, was not observed in their former experiments [11]. Moreover, studies from other laboratories concluded that $\mathrm{I}_{\mathrm{K} \text {,slow }}$ was fully insensitive to tolbutamide [12], and ascribed the current to activation of apamin-insensitive small-conductance $\mathrm{K}_{\mathrm{Ca}}(\mathrm{SK})$ channels [14]. Glucose appears to inhibit the component of $\mathrm{I}_{\mathrm{K} \text {,slow }}$ admittedly ascribed to $\mathrm{K}_{\mathrm{ATP}}$ channels $[13,15]$, leading to the hypothesis that it might provide the hyperpolarizing current necessary to terminate the burst. Bursting electrical activity and underlying $\left[\mathrm{Ca}^{2+}\right]_{i}$ oscillations are nonetheless present in mouse $\beta$-cells lacking the SUR1 gene [16-19], suggesting that channels distinct from the $\mathrm{K}_{\mathrm{ATP}}$ channel might account in part for physiological bursting and raising the possibility that they might mediate the graded electrical response to glucose. These channels may thus represent significant, albeit undervalued additional targets for glucose action downstream $\mathrm{K}_{\text {ATP }}$ channel inhibition.

We have previously shown that bursting electrical activity can be evoked by a variety of experimental manoeuvres that stimulate $\mathrm{Ca}^{2+}$ influx (e.g. raising $\left.\left[\mathrm{Ca}^{2+}\right]_{0}\right)$ in presence of sulphonylureas [20-23]. In this study, we used the sulphonylurea / high $\left[\mathrm{Ca}^{2+}\right]_{0}$ paradigm to characterize the glucose sensitivity of bursting and pulsatile 5-HT/insulin release in absence of functional $\mathrm{K}_{\mathrm{ATP}}$ channels. We report that products of the mitochondrial metabolism of glucose or derived messengers interact with channels underlying bursting, intensifying $\mathrm{Ca}^{2+}$ influx throughout an extended glucose concentration range. This translates into a graded secretory response to glucose in absence of functional $\mathrm{K}_{\text {ATP }}$ channels.

\section{Materials and Methods}

\section{Islet preparation and handling}

Except for membrane potential measurements, mouse pancreatic islets were isolated by collagenase digestion, as described [24, 25]. Islets were subsequently maintained in culture for 24 hours prior to the experiments, as reported [25]. For microamperometric recordings, islets were first cultured in standard medium supplemented with $11 \mathrm{mM}$ glucose (first 5-7 hours) and then in standard medium supplemented with $5.5 \mathrm{mM}$ glucose $+1 \mathrm{mM}$ 5-HT (remaining time). Fura-2 loading $(4 \mu \mathrm{M}$ fura-2/AM for 45 minutes at $37^{\circ} \mathrm{C}$ ) was carried out as described $[24,25]$. Fura-2 (or 5-HT)-loaded islets were transferred to a fast perifusion chamber placed on the stage of an inverted epifluorescence microscope, and subjected to perifusion at $37^{\circ} \mathrm{C}$ with a physiological salt solution containing (in $\mathrm{mM}$ ): $120 \mathrm{NaCl}, 5 \mathrm{KCl}, 25 \mathrm{NaHCO}_{3}, 2.56 \mathrm{CaCl}_{2}$, $1.1 \mathrm{MgCl}_{2}$ and glucose (concentration as required). This solution was constantly gassed with $95 \% \mathrm{O}_{2} / 5 \%$ $\mathrm{CO}_{2}$ for a $\mathrm{pH}$ of 7.4.

\section{Intracellular recording}

The membrane potential was recorded from microdissected islets using high-resistance (100-200 M $\Omega$ ) glass microelectrodes, as reported [21, 26]. Briefly, the islets were pinned to the plastic bottom of a fast perifusion chamber through which salt solution (composition as above) flowed at a rate of $2 \mathrm{~mL} /$ minute at $37^{\circ} \mathrm{C}$. The chamber was connected to ground through an agar bridge to minimize liquid junction potential variations due to changes in the ionic content of the solution.

\section{Current recording}

The perforated (nystatin) whole-cell patch-clamp technique was used to record total currents from isolated mouse $\beta$-cells, essentially as reported [27, 28]. Mouse islets were dispersed into isolated cells by trypsin digestion and cultured for 2-5 days, as reported [25]. All cells had a baseline capacitance $>5.5 \mathrm{pF}$, as reported for $\beta$-cells [29]. Patch pipettes were filled with a solution containing (in $\mathrm{mM}$ ): $63.7 \mathrm{KCl}, 28.4$ $\mathrm{K}_{2} \mathrm{SO}_{4}, 11.8 \mathrm{NaCl}, 1 \mathrm{MgCl}_{2}, 0.5$ EGTA, 47.2 sucrose, 20 HEPES and $250 \mu \mathrm{g} / \mathrm{mL}$ nystatin $(\mathrm{pH} 7.3$, adjusted with $\mathrm{KOH})$. Cells were perifused at $32-34^{\circ} \mathrm{C}$ with a salt solution containing (in $\mathrm{mM}$ ): $120 \mathrm{NaCl}, 5 \mathrm{KCl}$, $2.56 \mathrm{CaCl}_{2}, 1.13 \mathrm{MgCl}_{2}$ and 25 HEPES ( $\mathrm{pH} 7.3$, adjusted with $\mathrm{NaOH}$ ). 
$\left[\mathrm{Ca}^{2+}\right]_{i}$ recording

The $\left[\mathrm{Ca}^{2+}\right]_{\mathrm{i}}$ was recorded from single fura-2-loaded islets using a dual-excitation microfluorescence system, as described $[24,25]$. Briefly, fura-2 was excited at 340 and $380 \mathrm{~nm}$ via two monochromators and the fluorescence was detected by a photomultiplier, after passing through a band-pass interference filter centered at $510 \mathrm{~nm}$. The data were corrected for background fluorescence and acquired at $10 \mathrm{~Hz}$ by a computer. The fluorescence ratio $\mathrm{F}_{340} / \mathrm{F}_{380}$ was converted into $\left[\mathrm{Ca}^{2+}\right]_{\mathrm{i}}$ values as described $[25]$.

\section{5-HT release}

Release of pre-loaded 5-HT was monitored amperometrically using beveled glass-encased carbon fiber microelectrodes implanted in a single islet, as described $[8,30]$. Briefly, amperometric currents were measured using a pico-amperometer with the working electrode held at $+0.55 \mathrm{~V}$ vs. $\mathrm{Ag} / \mathrm{AgCl}$. Currents were low-pass filtered (cut-off frequency $100 \mathrm{~Hz}$ ), amplified $10 \times$ and stored on digital tape. Current recordings were initiated after 20-25 minutes had elapsed from the moment of insertion to allow full stabilization of electrode responses in situ [8]. Integral charge was determined as the time integral of the amperometric current, after subtraction of the respective background area.

\section{Materials}

Collagenase (type P) and staurosporine were purchased from Boehringer Mannheim Biochemicals (Mannheim, Germany). Fura-2/AM was from Molecular Probes (Eugene, OR, USA). All other chemicals were from Sigma Chemical Co. (St. Louis, MO, USA) or Merck (Darmstadt, Germany).

\section{Statistical analysis}

Results are expressed as mean \pm s.d. (main text) or mean \pm s.e.m. (figures). Statistical significance of differences between mean values was assessed by either one-way analysis of variance (ANOVA) followed by Bonferroni's multiple comparison test or paired Student's $t$-test, as appropriate (confidence level 95\%).

\section{Results}

Lowering glucose concentration from 11 to $3 \mathrm{mM}$ hyperpolarized the $\beta$-cell and suppressed bursting electrical activity (Fig. 1A). Addition of $500 \mu \mathrm{M}$ tolbutamide depolarized the cell and evoked continuous electrical activity. Raising the $\left[\mathrm{Ca}^{2+}\right]_{0}$ from 2.56 to $12.8 \mathrm{mM}$ in the continued presence of tolbutamide and $3 \mathrm{mM}$ glucose recovered a phasic pattern of electrical activity in a high proportion of the cells tested ( 9 of 12 cells; Fig. 1A). Raising the $\left[\mathrm{Ca}^{2+}\right]_{0}$ to lower levels is not enough to counteract the depolarizing action of sulphonylureas, as previously reported [21]. We have examined the glucose sensitivity of bursting by raising its concentration stepwise, at 15 minute intervals, in the continued presence of tolbutamide and high $\left[\mathrm{Ca}^{2+}\right]_{0}$. Fig. 1B depicts traces of electrical activity obtained at the steady-state (last 3 minutes) of each glucose concentration tested. Raising glucose from 3 to $11 \mathrm{mM}$ increased burst plateau duration by approximately $70 \%$ and slightly hyperpolarized $(\sim 4 \mathrm{mV})$ the $\beta$-cell at the inter-burst interval. The plateau potential remained essentially unchanged. Raising glucose to $30 \mathrm{mM}$ increased plateau duration further while leaving practically unaffected the inter-burst interval. Similar effects were obtained replacing tolbutamide for $5 \mu \mathrm{M}$ glibenclamide.

Fig. 1C shows the group data. Glucose increased plateau duration in a dose-dependent fashion (leftmost plot). Moreover, raising glucose from 3 to $11 \mathrm{mM}$ decreased the inter-burst interval in most experiments (not statistically significant as a whole; second plot from left). Consequently, glucose increased the average relative time spent at the burst plateau phase in a dose-dependent fashion (second plot from right). On average, raising glucose from 3 to $30 \mathrm{mM}$ increased fractional active phase duration from ca. 0.3 to 0.55 , an $83 \%$ change. High glucose did not evoke continuous spiking activity in presence of sulphonylurea and high $\left[\mathrm{Ca}^{2+}\right]_{0}$ in any of the cells tested, a situation generally found in presence of regular extracellular $\mathrm{Ca}^{2+}$ and absence of sulphonylurea [26]. Fig. 1C (rightmost plot) pools average spike frequency data from several experiments exhibiting overt spiking activity in $3 \mathrm{mM}$ glucose, sulphonylurea and high $\left[\mathrm{Ca}^{2+}\right]_{0}$. Glucose increased spike frequency in a dose-dependent fashion. Instantaneous spike frequency decayed along each burst; glucose increased markedly the respective time to half-decay $(2.0,3.3$ and 4.2 seconds for 3, 11 and 

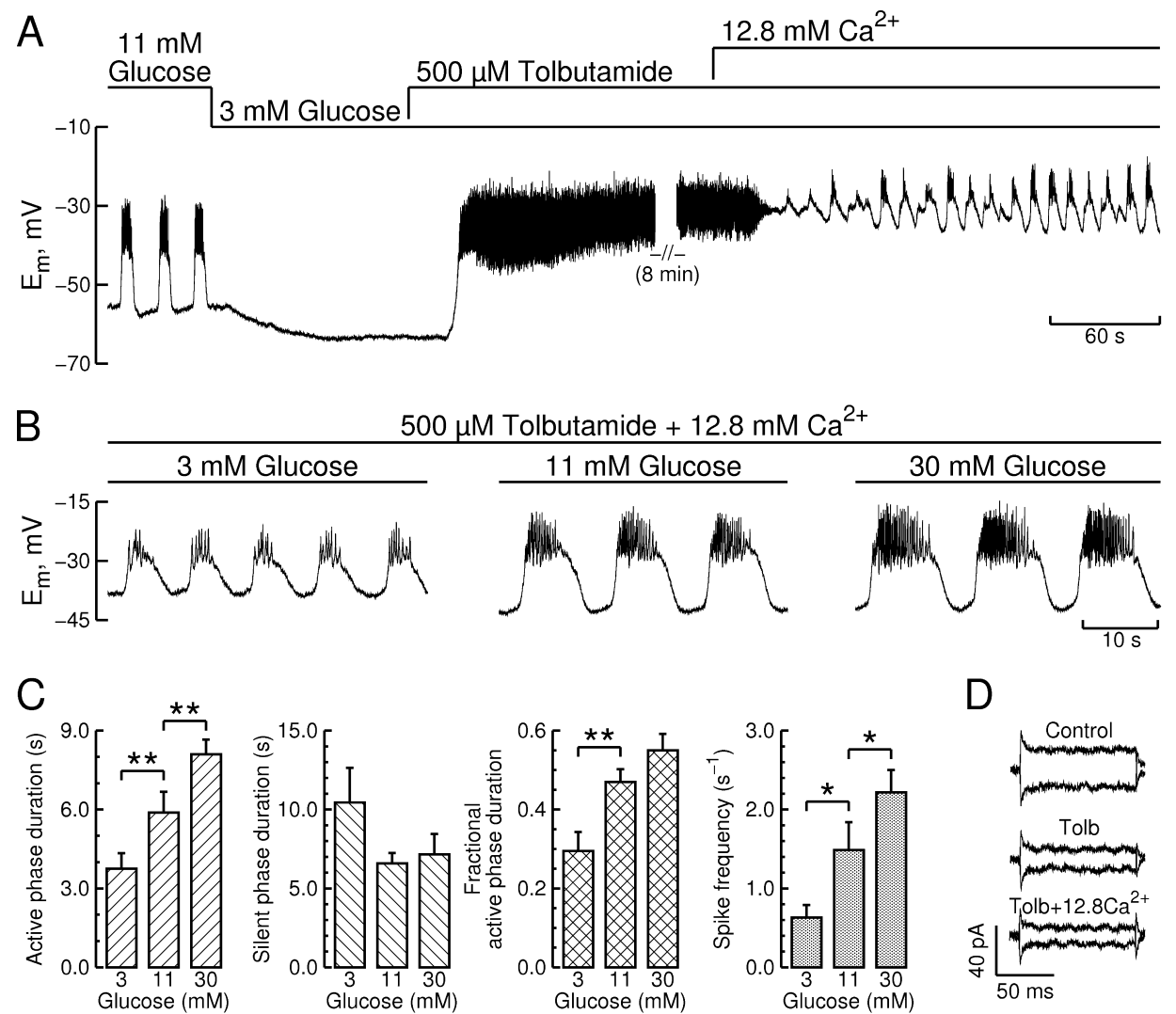

Fig. 1. Modulation of bursting electrical activity by glucose in presence of sulphonylurea and high $\left[\mathrm{Ca}^{2+}\right]_{0}$. A. Glucose concentration was lowered from 11 to $3 \mathrm{mM}$ and the $\left[\mathrm{Ca}^{2+}\right]_{\mathrm{o}}$ raised from 2.56 to $12.8 \mathrm{mM}$ in the continued presence of tolbutamide and $3 \mathrm{mM}$ glucose, as denoted by the step bars; B. Steady-state effects of glucose on bursting electrical activity, recorded from the same islet in the continued presence of tolbutamide and high $\left[\mathrm{Ca}^{2+}\right]_{\mathrm{o}}$ (last 3 minutes of 15 minute pulses for each glucose concentration). Glucose was raised stepwise in the order indicated. Also shown are selected segments of electrical activity on an expanded time basis; C. Effects of glucose on different bursting parameters, assessed at the steady-state under the experimental conditions depicted in B, except that tolbutamide (6 islets) was occasionally replaced for $5 \mu \mathrm{M}$ glibenclamide (3 islets). Spike frequency data were pooled from 7 islets exhibiting pronounced spiking activity in $3 \mathrm{mM}$ glucose, sulphonylurea and high $\left[\mathrm{Ca}^{2+}\right]_{0}$. Data are presented as mean \pm s.e.m. ${ }^{*}, \mathrm{p}<0.05 ; *$ * $<0.001$ by ANOVA/Bonferroni; D. Lack of effect of raising $\left[\mathrm{Ca}^{2+}\right]_{0}$ on $\mathrm{K}_{\mathrm{ATP}}$ channel currents. Total membrane currents were recorded from single $\beta$-cells in response to voltage pulses $( \pm 10 \mathrm{mV})$ applied from a holding potential of $-70 \mathrm{mV}$, prior to ("control") and throughout exposure to a

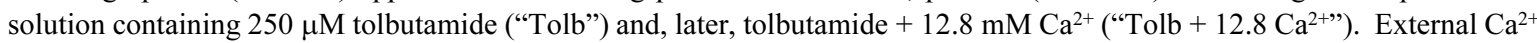
in control was $2.56 \mathrm{mM}$. Glucose was $3 \mathrm{mM}$ throughout. Data are representative of experiments on 8 different cells.

$30 \mathrm{mM}$ glucose, respectively). Compared to $3 \mathrm{mM}$ glucose, spike amplitude was also generally higher $(\sim 3-5 \mathrm{mV})$ at 11 or $30 \mathrm{mM}$ glucose.

Single mouse $\beta$-cells were voltage-clamped at -70 $\mathrm{mV}$ and subjected to repetitive $\pm 10 \mathrm{mV}$ pulses in $3 \mathrm{mM}$ glucose. Tolbutamide decreased total current and reduced the voltage-evoked currents by $71 \pm 7 \%$ $(\mathrm{n}=8$ cells), as illustrated in Fig. 1D. Importantly, raising the $\left[\mathrm{Ca}^{2+}\right]_{0}$ to $12.8 \mathrm{mM}$ in presence of tolbutamide did not affect the amplitude of the evoked currents (reduction in evoked currents relative to control: $73 \pm 8 \%){ }^{1}$ Thus, in presence of tolbutamide, the glo- bal hyperpolarizing effect of raising $\left[\mathrm{Ca}^{2+}\right]_{\mathrm{o}}$ is not simply due to sulphonylurea displacement from the SUR1

${ }^{1}$ We have also varied the applied voltage continuously from -100 to $+20 \mathrm{mV}$ under control and test conditions (data not shown). Currents below $-20 \mathrm{mV}$ were not affected by high $\mathrm{Ca}^{2+}{ }_{\mathrm{o}}$ in presence of tolbutamide, indicating that the effectiveness of the sulphonylurea as a $\mathrm{K}_{\mathrm{ATP}}$ channel blocker remained unchanged. High $\mathrm{Ca}^{2+}{ }_{0}$ caused $7 \mathrm{mV}$ rightward shifts of the I- $\mathrm{V}$ curves above $-20 \mathrm{mV}$. This is consistent with enhanced charge screening of anionic sites on the outer aspect of the cell membrane, leading to a reduction of voltage-sensitive $\mathrm{K}^{+}$currents. 

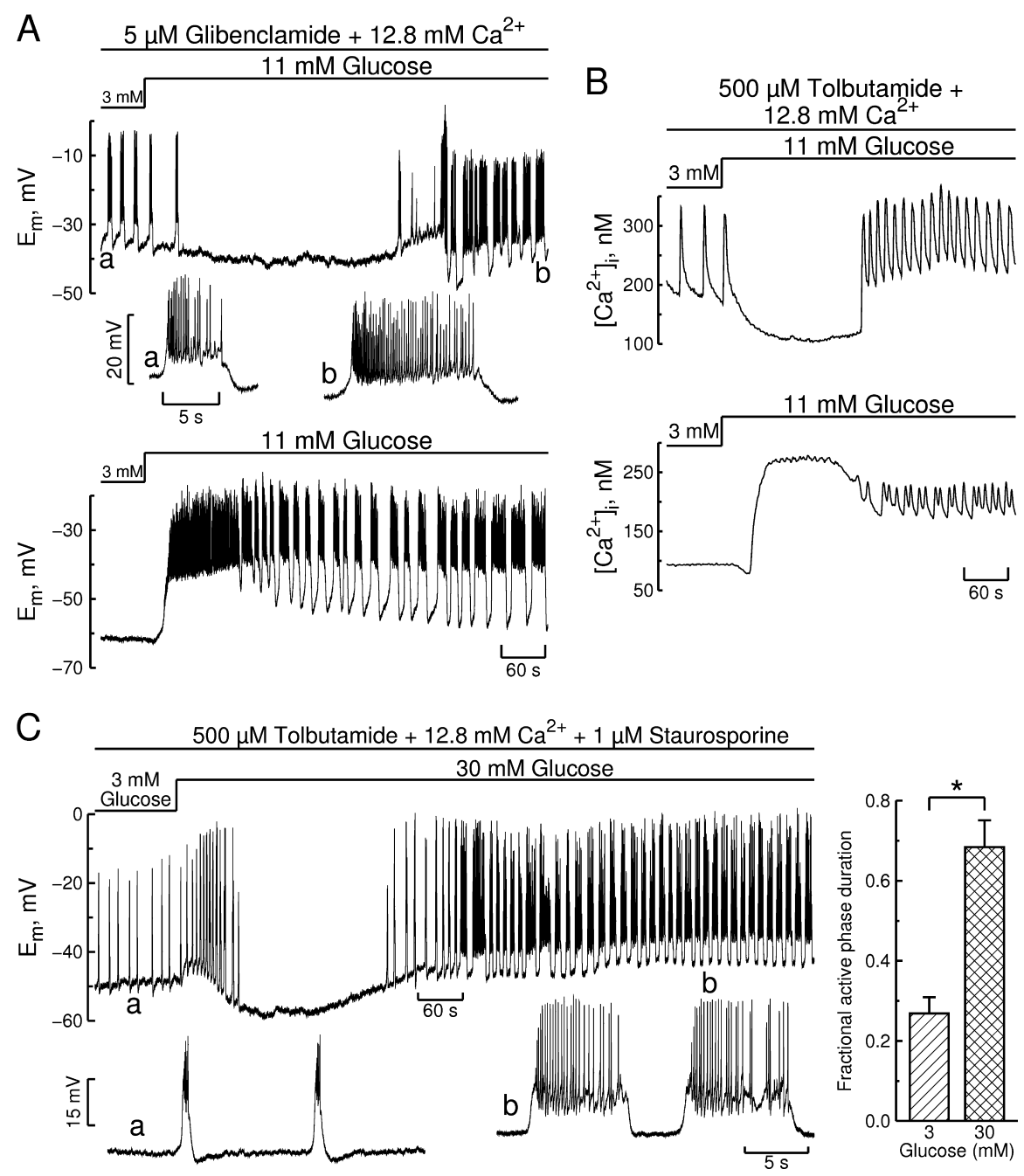

Fig. 2. Acute actions of glucose on bursting electrical activity and $\left[\mathrm{Ca}^{2+}\right]_{\mathrm{i}}$, and lack of effect of staurosporine. Glucose concentration was raised from $3 \mathrm{mM}$ to either $11 \mathrm{mM}(\mathrm{A}$ and $\mathrm{B})$ or $30 \mathrm{mM}(\mathrm{C})$ as denoted by the step bars, in the continued presence of sulphonylurea (glibenclamide or tolbutamide) $+12.8 \mathrm{mM} \mathrm{Ca}^{2+}$ (upper traces for each panel) or under standard conditions (no sulphonylurea and $2.56 \mathrm{mM} \mathrm{Ca}^{2+}$; lower traces for each panel, A and B). A. Membrane potential recordings from two different islets. Expanded segments of electrical activity are shown beneath the upper trace. Short-term suppression of electrical activity (upper trace) is representative of the effects observed in 4 similar experiments using either $5 \mu \mathrm{M}$ glibenclamide or $500 \mu \mathrm{M}$ tolbutamide; B. $\left[\mathrm{Ca}^{2+}\right]_{\mathrm{i}}$ recordings from two different islets. Short-term suppression of $\left[\mathrm{Ca}^{2+}\right]_{\mathrm{i}}$ oscillations (upper trace) is representative of the effects observed in 11 similar experiments using either $500 \mu \mathrm{M}$ tolbutamide or $5 \mu \mathrm{M}$ glibenclamide; C. Same as for the upper panel in A, except that glucose concentration was raised to $30 \mathrm{mM}$ in presence of $500 \mu \mathrm{M}$ tolbutamide, $12.8 \mathrm{mM} \mathrm{Ca}^{2+}$ and $1 \mu \mathrm{M}$ staurosporine. Exposure time to the kinase inhibitor prior to $30 \mathrm{mM}$ glucose: 15-20 minutes. Plot: fractional active phase duration at the steady-state of 3 and $30 \mathrm{mM}$ glucose. Data from the experiment depicted to the left and 2 similar experiments (presented as mean \pm s.e.m; ${ }^{*}, \mathrm{p}<0.05$ by paired Students' t-test).

binding site by either charge screening of anionic sites on the outer aspect of the cell membrane, raised $\left[\mathrm{Ca}^{2+}\right]_{\mathrm{i}}$ or some other unwanted effect.

Figs. 2A and 2B (upper traces) illustrate the acute effects of raising glucose from 3 to $11 \mathrm{mM}$ on bursting electrical activity and whole islet $\left[\mathrm{Ca}^{2+}\right]_{\mathrm{i}}$. Glucose suppressed the electrical activity by $4.0 \pm 0.6$ minutes
( $n=4$ islets) and hyperpolarized the $\beta$-cell below the inter-burst potential by $9 \pm 2 \mathrm{mV}$ (see Fig. 2A, upper trace). This was the mirror image of the prototypical effect observed under standard conditions (i.e. 2.56 $\mathrm{mM} \mathrm{Ca}^{2+}$ and no sulphonylurea; Fig. 2A, lower trace) and was matched by the transient disappearance of $\left[\mathrm{Ca}^{2+}\right]_{\mathrm{i}}$ oscillations and a pronounced $\left[\mathrm{Ca}^{2+}\right]_{\mathrm{i}}$ fall of 

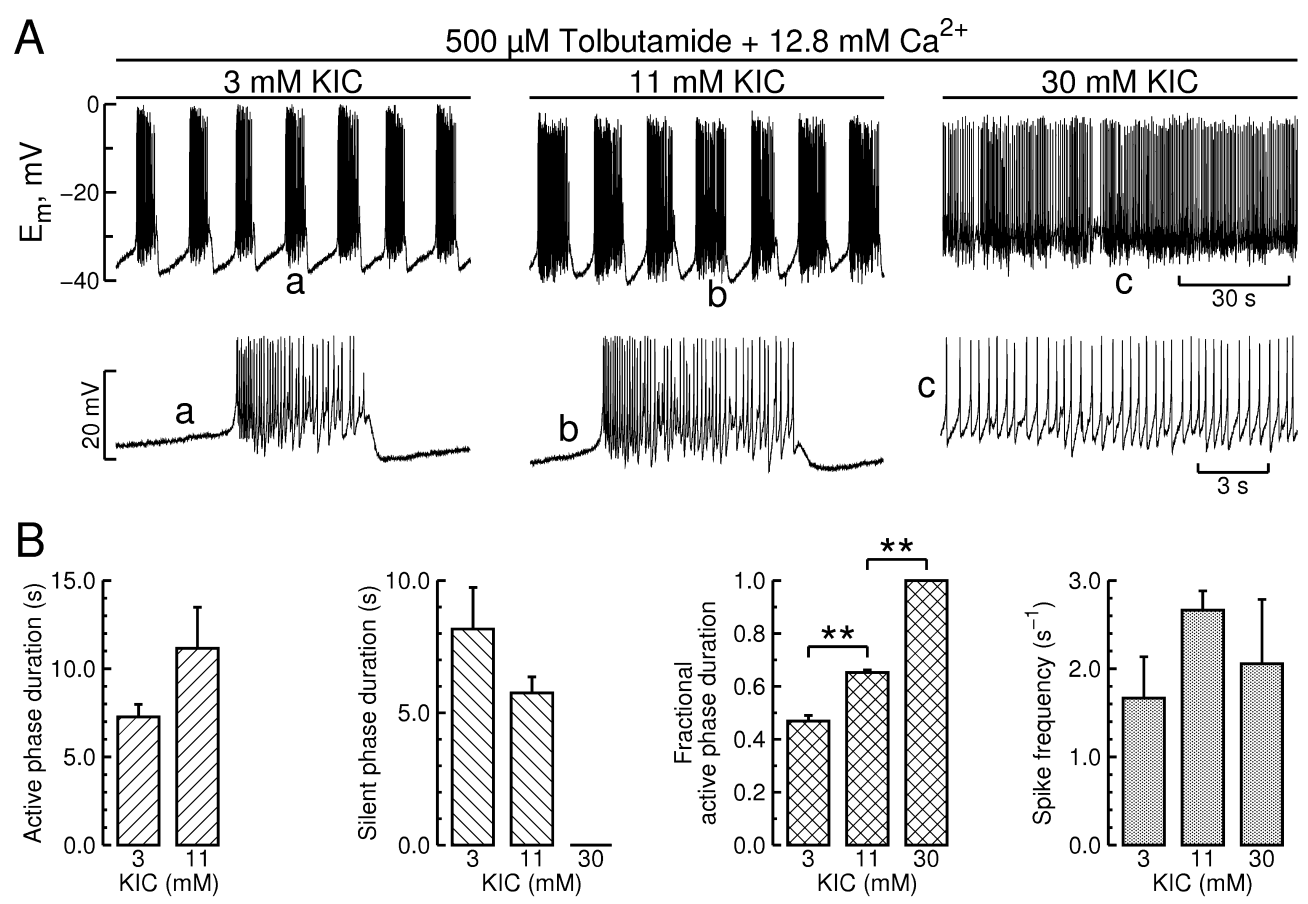

Fig. 3. Modulation of bursting electrical activity by KIC in presence of sulphonylurea and high $\left[\mathrm{Ca}^{2+}\right]_{0}$. A. Steady-state effects of KIC on bursting electrical activity, recorded in the continued presence of $500 \mu \mathrm{M}$ tolbutamide and $12.8 \mathrm{mM} \mathrm{Ca}^{2+}$ (last 3 minutes of 10 minute pulses at each KIC concentration). KIC concentration was raised stepwise in the order indicated. Also shown are selected segments of electrical activity on an expanded time basis; B. Effects of KIC on different parameters of bursting electrical activity, recorded under the same experimental conditions. Data from the experiment depicted in A and 2 similar experiments (presented as mean \pm s.e.m; ${ }^{* *}, \mathrm{p}<0.001$ by ANOVA/Bonferroni).

$\sim 60 \mathrm{nM}$ lasting $4 \pm 1$ minutes $(\mathrm{n}=11$ islets; see Fig. $2 \mathrm{~B}$, upper trace). The latter was again the mirror image of the prototypical effect under standard conditions (i.e. a sharp transition to a high $\mathrm{Ca}^{2+}$ level; Fig. 2B, lower trace). The short-term stimulatory actions of glucose on both membrane potential and $\left[\mathrm{Ca}^{2+}\right]_{\mathrm{i}}$ reflect closure of $\mathrm{K}_{\mathrm{ATP}}$ channels. Therefore, the contrasting effects recorded in presence of sulphonylurea and high $\left[\mathrm{Ca}^{2+}\right]_{\mathrm{o}}$ provided a further internal control for the absence of functional $\mathrm{K}_{\mathrm{ATP}}$ channels.

Fig. $2 \mathrm{C}$ shows that neither the immediate nor the sustained effects of glucose originated from activation of serine/threonine protein kinases. Indeed, islets treated with $1 \mu \mathrm{M}$ staurosporine, a general inhibitor of these kinases [31], exhibited a robust transient hyperpolarization upon exposure to $30 \mathrm{mM}$ glucose in presence of sulphonylurea and high $\left[\mathrm{Ca}^{2+}\right]_{0}$; likewise, staurosporine did not affect the sustained stimulatory effect of glucose on bursting electrical activity (Fig. $2 \mathrm{C}$, plot). Islets displayed a similar insensitivity to $100 \mu \mathrm{M}$ Rp-cAMPS, a specific competitive inhibitor of protein kinase A (PKA) that resembles endogenous
cAMP [32] (data not shown).

$\alpha$-Ketoisocaproic acid (KIC), the transamination product of leucine, bypasses glycolysis and is directly metabolized by the mitochondria to $\alpha$-ketoglutarate and acetyl-CoA, which may serve as precursors for anaplerosis and substrates for energy production in $\beta$ cells [33]. As shown in Fig. 3A (leftmost trace), islets displayed membrane potential oscillations in presence of tolbutamide, high $\left[\mathrm{Ca}^{2+}\right]_{\mathrm{o}}$ and $3 \mathrm{mM} \mathrm{KIC}$. Raising KIC concentration stepwise from 3 to $30 \mathrm{mM}$ increased burst plateau duration and decreased the interburst interval in a glucose-like manner. Contrary to glucose the highest KIC concentration used $(30 \mathrm{mM})$ turned the bursting mode into a tonic firing pattern (Fig. 3A, rightmost trace). Fig. 3B shows the group data. KIC $(30 \mathrm{mM})$ increased fractional active phase duration by ca. $100 \%$. Raising KIC from 3 to $11 \mathrm{mM}$ increased average spike frequency, an effect that nonetheless lacked statistical significance and appeared to have become attenuated at $30 \mathrm{mM} \mathrm{KIC}$, presumably as a consequence of the slower and longer action potentials that are typically recorded under continuous spike 

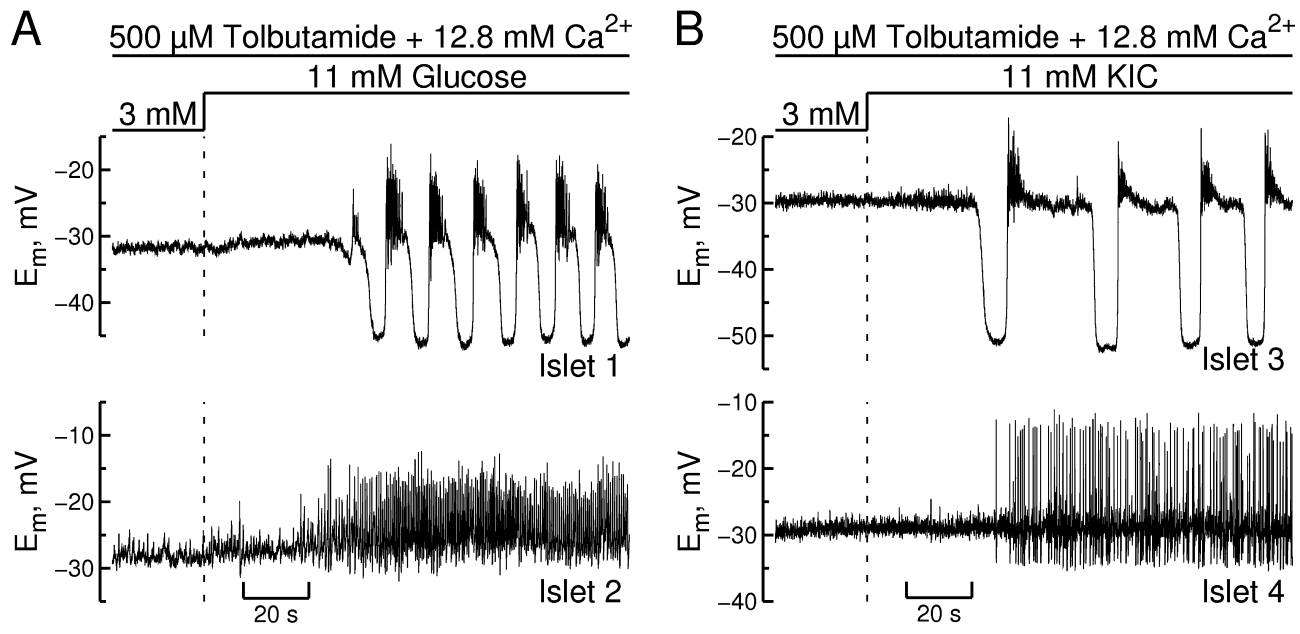

Fig. 4. Effect of raising glucose or KIC concentration on membrane potential in presence of sulphonylurea and high $\left[\mathrm{Ca}^{2+}\right]_{\mathrm{o}}$, in cells lacking bursting electrical activity in low glucose or KIC. Glucose (A) or $\alpha$-ketoisocaproic acid (KIC) concentration (B) was raised from 3 to $11 \mathrm{mM}$ as denoted by the step bars, in the continued presence of $12.8 \mathrm{mM} \mathrm{Ca}^{2+}$ and $500 \mu \mathrm{M}$ tolbutamide. The traces labelled "islet 1" and "islet 3" are representative of experiments where raising glucose or KIC concentration evoked a bursting pattern of electrical activity (4 islets). The traces labelled "islet 2" and "islet 4" are representative of experiments where raising glucose or KIC concentration enhanced spiking activity without affecting the inter-spike membrane potential (3 islets).

firing. Exposing the islets to high KIC did not evoke the characteristic short-term inhibitory effect of glucose (data not shown).

Figs. 1 and 2 are representative of cells which developed bursting electrical activity when challenged with high $\mathrm{Ca}^{2+}$ in presence of sulphonylurea and $3 \mathrm{mM}$ glucose. However, a fraction of the cells (ca. 25\%) did not exhibit bursting under these conditions. As shown in Fig. 4A, non-oscillating cells typically exhibited low amplitude $(<5 \mathrm{mV})$ spikes firing from a membrane potential of about $-30 \mathrm{mV}$. The $\left[\mathrm{Ca}^{2+}\right]_{\mathrm{i}}$ counterpart of islets lacking bursting activity was a complete lack of $\left[\mathrm{Ca}^{2+}\right]_{\mathrm{i}}$ oscillations (data not shown). Raising glucose from 3 to $11 \mathrm{mM}$ either markedly enhanced the electrical activity at a sustained plateau (Fig. 4A, islet 2) or triggered a bursting pattern, with overt spikes firing from a plateau potential close to that in $3 \mathrm{mM}$ glucose (islet 1). Irrespectively of the response pattern, spike amplitude in $11 \mathrm{mM}$ glucose was clearly augmented. Fig. 4B depicts cells lacking bursting electrical activity in $3 \mathrm{mM} \mathrm{KIC}$, tolbutamide and high $\left[\mathrm{Ca}^{2+}\right]_{0}$. Raising KIC concentration to $11 \mathrm{mM}$ had glucose-like effects on these cells.

We assessed the effect of raising glucose concentration stepwise on whole islet $\left[\mathrm{Ca}^{2+}\right]_{\mathrm{i}}$ oscillations in presence of tolbutamide and high $\left[\mathrm{Ca}^{2+}\right]_{0}$. Tolbutamide evoked a prompt and sustained $\left[\mathrm{Ca}^{2+}\right]_{\mathrm{i}}$ rise in presence of $3 \mathrm{mM}$ glucose and regular external $\mathrm{Ca}^{2+}$, which became oscillatory once the $\left[\mathrm{Ca}^{2+}\right]_{\mathrm{o}}$ was raised to $12.8 \mathrm{mM}$ (leftmost portion of the main trace in Fig. 5A). Raising glucose concentration stepwise augmented the duration of the $\left[\mathrm{Ca}^{2+}\right]_{\mathrm{i}}$ oscillations at the steady-state while leaving its amplitude essentially unchanged (see expanded records and the group data in Fig. 5B). Enhancement of $\left[\mathrm{Ca}^{2+}\right]_{\mathrm{i}}$ oscillations was often preceded by transient periods with either no oscillations or a less intense pattern of oscillatory activity.

Raising glucose concentration stepwise also had marked effects on 5-HT/insulin release in presence of tolbutamide and high $\left[\mathrm{Ca}^{2+}\right]_{0}$. 5-HT release was monitored amperometrically using carbon fiber microelectrodes implanted in single preloaded islets. Adding tolbutamide in presence of $3 \mathrm{mM}$ glucose increased steeply the amperometric current arising from 5-HT oxidation at the surface of the electrode (data not shown). Raising the $\left[\mathrm{Ca}^{2+}\right]_{\text {o }}$ from 2.56 to $12.8 \mathrm{mM}$ evoked a pattern of oscillatory 5-HT release (leftmost portion of the trace in Fig. 5C) resembling that evoked by glucose under standard conditions [30]. Importantly, raising glucose concentration stepwise in the range 3-30 mM caused successive increments in the amount of 5-HT released per oscillation at the steady-state, as evidenced by an increase in both amplitude and duration of the individual oscillations (trace in Fig. 5C). This resulted in a dose-dependent increase in the 
A

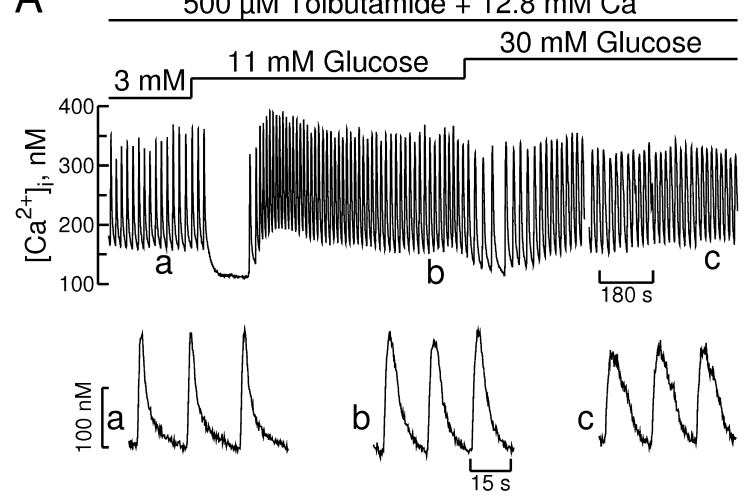

$\mathrm{B}$

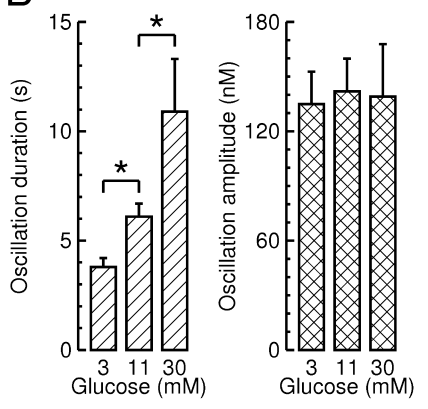

C

$500 \mu \mathrm{M}$ Tolbutamide $+12.8 \mathrm{mM} \mathrm{Ca}^{2+}$
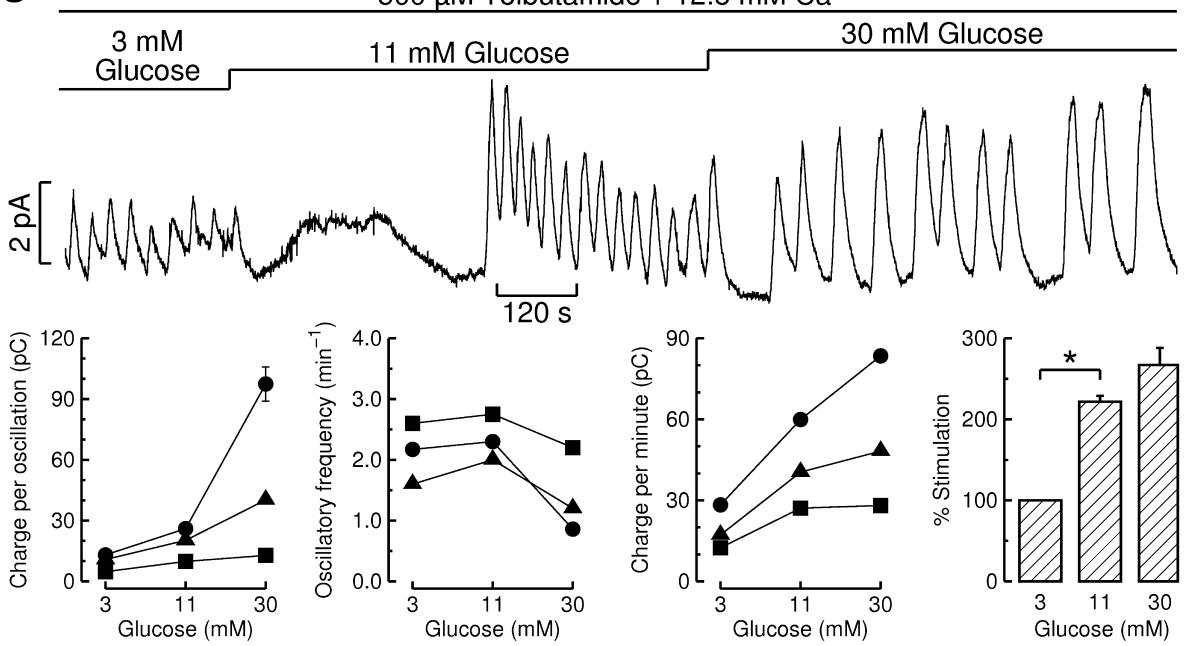

Fig. 5. Modulation of $\left[\mathrm{Ca}^{2+}\right]_{\mathrm{i}}$ oscillations and pulsatile 5-HT release by glucose in presence of sulphonylurea and high $\left[\mathrm{Ca}^{2+}\right]_{\mathrm{o}}$. A. Trace: Continuous $\left[\mathrm{Ca}^{2+}\right]_{\mathrm{i}}$ recording from a fura-2-loaded islet. Glucose concentration was raised stepwise in the continued presence of $500 \mu \mathrm{M}$ tolbutamide and high $\left[\mathrm{Ca}^{2+}\right]_{\mathrm{o}}$. Also shown are details of $\left[\mathrm{Ca}^{2+}\right]_{\mathrm{i}}$ oscillations on an expanded time scale; B. Effects of glucose on parameters of $\left[\mathrm{Ca}^{2+}\right]_{\mathrm{i}}$ oscillations, measured at the steady-state. Data from the experiment depicted in A and similar experiments (presented as mean \pm s.e.m., $\mathrm{n}=5$ islets; ${ }^{*}, \mathrm{p}<0.05$ by ANOVA/Bonferroni); C. Trace: Continuous amperometric recording from a 5-HT-preloaded islet. Glucose concentration was raised stepwise in the continued presence of tolbutamide and high $\left[\mathrm{Ca}^{2+}\right]_{0}$. Plots: Glucose dependency of pulsatile 5-HT release in presence of tolbutamide and high $\left[\mathrm{Ca}^{2+}\right]_{0}$, assessed from the experiment depicted by the trace (circles) and two other similar experiments. Parameters were measured at the steady-state of each glucose concentration. Overall 5-HT secretory rate (charge per minute) was estimated as the product of oscillatory frequency and average charge per oscillation (average time integral of individual oscillations). Rightmost plot: replot of the data in the third plot, normalized to the average release rate in $3 \mathrm{mM}$ glucose. Data are presented as mean \pm s.e.m. (charge per oscillation: $\mathrm{n}=6$ oscillations; $\%$ stimulation: $\mathrm{n}=3$ islets; ${ }^{*}, \mathrm{p}<0.05$ by ANOVA/Bonferroni). Leftmost plot: the size of the error bars was generally lower than symbol size.

charge produced per oscillation, a measure of the amount of 5-HT released per oscillation (Fig. 5C, leftmost plot). The overall 5-HT secretory rate at the steady-state, estimated as the product of average charge produced per oscillation and oscillatory frequency, increased with glucose in a dose-dependent fashion (third plot from left). Stimulation of pulsatile 5-HT release was often preceded by transient periods with no 5-HT activity.

\section{Discussion}

We show that, in absence of functional $\mathrm{K}_{\mathrm{ATP}}$ channels, glucose mimics to a large extent the membrane potential effects observed under regular physiological conditions. Indeed, glucose increases in a dose-dependent fashion burst plateau duration, spike frequency and the duration of the associated $\left[\mathrm{Ca}^{2+}\right]_{\mathrm{i}}$ oscillations. This translates into a dose-dependent enhancement of 
pulsatile 5-HT/insulin release. Thus, our results indicate that other ion channels besides the $\mathrm{K}_{\text {ATP }}$ channel are prone to regulation by products of glucose metabolism or related messengers, and suggest that this regulation might contribute to the graded physiological response to glucose.

KIC bypasses glycolysis and feeds directly the TCA cycle. We found that KIC mimics largely the stimulatory effect of glucose in absence of functional $\mathrm{K}_{\mathrm{ATP}}$ channels, indicating that the regulatory signals originate from mitochondria. Besides stimulating ATP production both the keto-acid and glucose inhibit $\beta$ oxidation via anaplerotic generation of malonyl-CoA, probably raising cytosolic long-chain acyl-CoA levels and stimulating complex lipid formation including diacylglycerols [34]. It would seem therefore plausible that cPKC and/or nPKC might be involved in the stimulatory action of glucose reported in this study. Neither PKC nor other serine/threonine protein kinases are however involved, as indicated by the lack of effect of staurosporine and Rp-cAMPS.

Cells displaying incipient spiking and lacking bursting activity in high $\mathrm{Ca}^{2+}{ }_{\mathrm{o}}$ and low glucose (or KIC) developed a pattern of intensified continuous spiking or bursting in response to $11 \mathrm{mM}$ glucose. This strongly suggests that glucose enhances voltage-sensitive $\mathrm{Ca}^{2+}$ channel activity, in agreement with previous studies on voltage-clamped mouse $\beta$-cells $[35,36]$ and insulinsecreting RINm5F cells [37]. Also significantly, glucose-induced $\left[\mathrm{Ca}^{2+}\right]_{\mathrm{i}}$ rises recorded from SUR1 knockout mouse islets are strictly dependent on $\mathrm{Ca}^{2+}{ }_{0}$ and mediated by dihydropyridine-sensitive $\mathrm{Ca}^{2+}$ channels [19]. Moreover, the mitochondrial poison azide inhibits both L-type $\mathrm{Ca}^{2+}$ currents in normal $\beta$-cells [38] and spiking activity in depolarized SUR(-/-) $\beta$-cells [16]. $\mathrm{Ca}_{\mathrm{V}} 1$ channels are the prevailing high-voltage activated $\mathrm{Ca}^{2+}$ channels mediating fast $\mathrm{Ca}^{2+}$ signaling and insulin exocytosis $[39,40]$. It is well established that activation of these channels accounts for the initial outburst of $\mathrm{Ca}^{2+}$ influx and insulin release (first phase), in response to $\mathrm{K}_{\mathrm{ATP}}$ channel inhibition and membrane depolarization. Based in our findings, we hypothesize that up-regulation of $\mathrm{Ca}_{\mathrm{V}} 1$ channels by glucose metabolism may lengthen the burst plateau phase, thus providing a mechanism for the fine tuning of oscillatory $\mathrm{Ca}^{2+}$ influx along the second phase of glucose-induced insulin secretion. We note that phosphorylation-independent regulation of L-type $\mathrm{Ca}^{2+}$ channels by either ATP, MgATP or $\mathrm{Mg}^{2+}$ has been demonstrated in cardi- ac myocytes and other cell types [41-45], including cells expressing cloned $\mathrm{Ca}_{\mathrm{V}} 1.2$ channels [46].

Delayed rectifier $\mathrm{K}^{+}(\mathrm{Kv})$ channels, notably $\mathrm{Kv} 2.1$, have received considerable attention in recent years as potential regulators of glucose-induced electrical activity and insulin secretion, owing to the fact that they provide most of the outward current that mediates spike repolarization in $\beta$-cells and, thus, play an important role in limiting $\mathrm{Ca}^{2+}$ influx along an action potential [47]. Two gut-derived hormones, ghrelin and glucagon-like peptide-1, were recently found to regulate $\mathrm{Kv}$ channel currents through mechanisms involving G-proteins and, at least for GLP-1, the cAMP/PKA signaling system $[48,49]$. Since glucose increases intracellular cAMP levels slightly, nucleotide-mediated inhibition of these currents might conceivably enhance $\beta$-cell excitability and therefore contribute to the stimulatory effect of glucose reported here. However, this hypothesis is not supported by the negative effects of staurosporine and Rp-cAMPS (see above).

It should be pointed out that tolbutamide evokes continuous spike firing in presence of medium-high glucose and regular extracellular $\mathrm{Ca}^{2+}$. This would be consistent with the idea that a fraction of $\mathrm{K}_{\mathrm{ATP}}$ channels is active under these conditions, either because the glucose-induced increase in the cytosolic ATP/ADP ratio might be insufficient to close all channels or because enhanced $\mathrm{Ca}^{2+}$-ATPase activity might lower ATP levels at the sub-membrane region. Thus, residual $\mathrm{K}_{\mathrm{ATP}}$ channel current may play a role in the feedback loop relating other hyperpolarizing currents and $\mathrm{Ca}^{2+}$ current, permitting physiological bursting at regular external $\mathrm{Ca}^{2+}$.

Elucidating the nature of the hyperpolarizing currents that may account for the burst silent phase was clearly not an objective of the present study. We note however that, although other studies have considered different putative pacemaker channels (e.g. large- and small-conductance $\mathrm{K}_{\mathrm{Ca}}$ channels), the proposed mechanisms remain elusive [50]. For example, the largeconductance $\mathrm{K}_{\mathrm{Ca}}$ channel, a long-held candidate to a "burster" channel in $\beta$-cells, can only be activated at membrane potentials above the burst plateau potential; further, specific blockade of this channel does not affect bursting electrical activity [51]. More recent studies indicate that hyperpolarization-activated cyclic nucleotide-modulated ( $\mathrm{HCN}$ ) channels, responsible for cardiac pacemaking, also do not seem to be involved in $\beta$-cell bursting [52]. 
In summary, we conclude that $\beta$-cells exhibit graded oscillatory electrical and secretory responses to glucose in absence of functional $\mathrm{K}_{\mathrm{ATP}}$ channels. Voltagesensitive $\mathrm{Ca}^{2+}$ channels may act as supplementary sensors of metabolic energy, emphasizing the need to investigate in depth the mechanisms underlying bursting electrical activity. The $\mathrm{K}_{\mathrm{ATP}}$ channel-independent system used in this study may represent a practical and valuable model to foster research in this area.

\section{Acknowledgements}

We gratefully acknowledge the School of Medicine at the University of Coimbra for providing essential facilities. This study was supported in part by Fundação para a Ciência e Tecnologia (FCT, Portugal).

\section{References}

1. MacDonald PE, Joseph JW, Rorsman P (2005) Glucose-sensing mechanisms in pancreatic $\beta$-cells. Philos Trans R Soc Lond B Biol Sci 360: 2211-2225.

2. Sato Y, Aizawa T, Komatsu M, Okada N, Yamada T (1992) Dual functional role of membrane depolarization/ $\mathrm{Ca}^{2+}$ influx in rat pancreatic B-cell. Diabetes 41: 438-443.

3. Gembal M, Gilon P, Henquin JC (1992) Evidence that glucose can control insulin release independently from its action on ATP-sensitive $\mathrm{K}^{+}$channels in mouse B cells. J Clin Invest 89: 1288-1295.

4. Straub SG, Sharp GW (2002) Glucose-stimulated signaling pathways in biphasic insulin secretion. Diabetes Metab Res Rev 18: 451-463.

5. Henquin JC, Ravier MA, Nenquin M, Jonas JC, Gilon P (2003) Hierarchy of the $\beta$-cell signals controlling insulin secretion. Eur J Clin Invest 33: 742-750.

6. Rosario LM, Atwater I, Scott AM (1986) Pulsatile insulin release and electrical activity from single ob/ob mouse islets of Langerhans. Adv Exp Med Biol 211: 413-425.

7. Santos RM, Rosario LM, Nadal A, Garcia-Sancho J, Soria B, Valdeolmillos M (1991) Widespread synchronous $\left[\mathrm{Ca}^{2+}\right]_{\mathrm{i}}$ oscillations due to bursting electrical activity in single pancreatic islets. Pflugers Arch 418: 417422.

8. Barbosa RM, Silva AM, Tome AR, Stamford JA, Santos RM, Rosario LM (1998) Control of pulsatile 5 -HT/insulin secretion from single mouse pancreatic islets by intracellular calcium dynamics. $J$ Physiol 510: 135-143.

9. Sanchez-Andres JV, Gomis A, Valdeolmillos M (1995) The electrical activity of mouse pancreatic $\beta$-cells recorded in vivo shows glucose-dependent oscillations. J Physiol 486: 223-228.

10. Porksen N, Hollingdal M, Juhl C, Butler P, Veldhuis JD, Schmitz O (2002) Pulsatile insulin secretion: detection, regulation, and role in diabetes. Diabetes 51: S245-S254.

11. Gopel SO, Kanno T, Barg S, Eliasson L, Galvanovskis
J, Renstrom E, Rorsman P (1999) Activation of $\mathrm{Ca}^{2+}$ dependent $\mathrm{K}^{+}$channels contributes to rhythmic firing of action potentials in mouse pancreatic $\beta$ cells. $J$ Gen Physiol 114: 759-770.

12. Goforth PB, Bertram R, Khan FA, Zhang M, Sherman A, Satin LS (2002) Calcium-activated $\mathrm{K}^{+}$channels of mouse $\beta$-cells are controlled by both store and cytoplasmic $\mathrm{Ca}^{2+}$ : experimental and theoretical studies. $J$ Gen Physiol 120: 307-322.

13. Kanno T, Rorsman P, Gopel SO (2002) Glucosedependent regulation of rhythmic action potential firing in pancreatic $\beta$-cells by $\mathrm{K}_{\mathrm{ATP}}$-channel modulation. J Physiol 545: 501-507.

14. Zhang M, Houamed K, Kupershmidt S, Roden D, Satin LS (2005) Pharmacological properties and functional role of $\mathrm{K}_{\text {slow }}$ current in mouse pancreatic $\beta$-cells: SK channels contribute to $K_{\text {slow }}$ tail current and modulate insulin secretion. J Gen Physiol 126: 353-363.

15. Rolland JF, Henquin JC, Gilon P (2002) Feedback control of the ATP-sensitive $\mathrm{K}^{+}$current by cytosolic $\mathrm{Ca}^{2+}$ contributes to oscillations of the membrane potential in pancreatic $\beta$-cells. Diabetes 51: 376-384.

16. Dufer M, Haspel D, Krippeit-Drews P, Aguilar-Bryan L, Bryan J, Drews G (2004) Oscillations of membrane potential and cytosolic $\mathrm{Ca}^{2+}$ concentration in SUR1(-/-) beta cells. Diabetologia 47: 488-498.

17. Nenquin M, Szollosi A, Aguilar-Bryan L, Bryan J, Henquin JC (2004) Both triggering and amplifying pathways contribute to fuel-induced insulin secretion in the absence of sulfonylurea receptor- 1 in pancreatic $\beta$ cells. J Biol Chem 279: 32316-32324.

18. Haspel D, Krippeit-Drews P, Aguilar-Bryan L, Bryan J, Drews G, Dufer M (2005) Crosstalk between membrane potential and cytosolic $\mathrm{Ca}^{2+}$ concentration in $\beta$ cells from Sur1-/- mice. Diabetologia 48: 913-921.

19. Szollosi A, Nenquin M, Aguilar-Bryan L, Bryan J, Henquin JC (2007) Glucose stimulates $\mathrm{Ca}^{2+}$ influx and insulin secretion in 2-week-old $\beta$-cells lacking ATPsensitive $\mathrm{K}^{+}$channels. J Biol Chem 282: 1747-1756.

20. Santos RM, Barbosa RM, Silva AM, Antunes CM, 
Rosario LM (1992) High external $\mathrm{Ca}^{2+}$ levels trigger membrane potential oscillations in mouse pancreatic $\beta$-cells during blockade of $\mathrm{K}_{\mathrm{ATP}}$ channels. Biochem Biophys Res Commun 187: 872-879.

21. Rosario LM, Barbosa RM, Antunes CM, Silva AM, Abrunhosa AJ, Santos RM (1993) Bursting electrical activity in pancreatic $\beta$-cells: evidence that the channel underlying the burst is sensitive to $\mathrm{Ca}^{2+}$ influx through L-type $\mathrm{Ca}^{2+}$ channels. Pflugers Arch 424: 439-447.

22. Barbosa RM, Salgado AP, Santos RM, Rosario LM (1993) Differential modulation of pancreatic $\beta$-cell bursting by intracellular $\mathrm{pH}$ in the presence and absence of a K-ATP channel blocker. FEBS Lett 332: 913.

23. Santos RM, Barbosa RM, Silva AM, Antunes CM, Rosário LM (1994) $\left[\mathrm{Ca}^{2+}\right]_{\mathrm{i}}$-sensitive conductance in the regulation of pancreatic B-cell bursting. In: Flatt PR, Lenzen $S$ (eds) Insulin secretion and pancreatic B-cell research. Smith-Gordon, UK, 181-186.

24. Silva AM, Rosario LM, Santos RM (1994) Background $\mathrm{Ca}^{2+}$ influx mediated by a dihydropyridine- and voltage-insensitive channel in pancreatic $\beta$-cells. Modulation by $\mathrm{Ni}^{2+}$, diphenylamine-2-carboxylate, and glucose metabolism. J Biol Chem 269: 17095-17103.

25. Salgado A, Silva AM, Santos RM, Rosario LM (1996) Multiphasic action of glucose and $\alpha$-ketoisocaproic acid on the cytosolic $\mathrm{pH}$ of pancreatic $\beta$-cells. Evidence for an acidification pathway linked to the stimulation of $\mathrm{Ca}^{2+}$ influx. J Biol Chem 271: 8738-8746.

26. Antunes CM, Salgado AP, Rosario LM, Santos RM (2000) Differential patterns of glucose-induced electrical activity and intracellular calcium responses in single mouse and rat pancreatic islets. Diabetes 49: 2028-2038.

27. Silva AM, Liu-Gentry J, Dickey AS, Barnett DW, Misler S (2005) $\alpha$-Latrotoxin increases spontaneous and depolarization-evoked exocytosis from pancreatic islet $\beta$-cells. J Physiol 565: 783-799.

28. Silva AM, Rodrigues RJ, Tome AR, Cunha RA, Misler S, Rosário LM, Santos RM (2008) Electrophysiological and immunocytochemical evidence for $\mathrm{P} 2 \mathrm{X}$ purinergic receptors in pancreatic $\beta$-cells. Pancreas 36: 279-283.

29. Gopel S, Kanno T, Barg S, Galvanovskis J, Rorsman P (1999) Voltage-gated and resting membrane currents recorded from B-cells in intact mouse pancreatic islets. J Physiol 521: 717-728.

30. Baldeiras IE, Santos RM, Rosario LM (2006) Protein kinase $\mathrm{C}$ isoform specificity of cholinergic potentiation of glucose-induced pulsatile 5-HT/ insulin release from mouse pancreatic islets. Biol Res 39: 531-539.

31. Ruegg UT, Burgess GM (1989) Staurosporine, K-252 and UCN-01: potent but nonspecific inhibitors of protein kinases. Trends Pharmacol Sci 10: 218-220.

32. Rothermel JD, Parker Botelho LH (1988) A mechanistic and kinetic analysis of the interactions of the diaste- reoisomers of adenosine 3',5'-(cyclic)phosphorothioate with purified cyclic AMP-dependent protein kinase. Biochem J 251: 757-762.

33. MacDonald MJ, Fahien LA, Brown LJ, Hasan NM, Buss JD, Kendrick MA (2005) Perspective: emerging evidence for signaling roles of mitochondrial anaplerotic products in insulin secretion. Am J Physiol Endocrinol Metab 288: E1-15.

34. Corkey BE, Deeney JT, Yaney GC, Tornheim K, Prentki M (2000) The role of long-chain fatty acylCoA esters in $\beta$-cell signal transduction. J Nutr 130 : 299S-304S.

35. Smith PA, Rorsman P, Ashcroft FM (1989) Modulation of dihydropyridine-sensitive $\mathrm{Ca}^{2+}$ channels by glucose metabolism in mouse pancreatic $\beta$-cells. Nature 342: 550-553.

36. Kato $\mathrm{S}$, Ishida $\mathrm{H}$, Tsuura $\mathrm{Y}$, Tsuji K, Nishimura M, Horie M, Taminato T, Ikehara S, Odaka H, Ikeda I, Okada Y, Seino Y (1996) Alterations in basal and glucose-stimulated voltage-dependent $\mathrm{Ca}^{2+}$ channel activities in pancreatic $\beta$ cells of non-insulin-dependent diabetes mellitus GK rats. J Clin Invest 97: 2417-2425.

37. Velasco JM, Petersen JU, Petersen OH (1988) Singlechannel $\mathrm{Ba}^{2+}$ currents in insulin-secreting cells are activated by glyceraldehyde stimulation. FEBS Lett 231: 366-370.

38. Dufer M, Krippeit-Drews P, Drews G (2002) Inhibition of mitochondrial function affects cellular $\mathrm{Ca}^{2+}$ handling in pancreatic B-cells. Pflugers Arch 444: 236-243.

39. Yang SN, Berggren PO (2006) The role of voltagegated calcium channels in pancreatic $\beta$-cell physiology and pathophysiology. Endocr Rev 27: 621-676.

40. Schulla V, Renstrom E, Feil R, Feil S, Franklin I, Gjinovci A, Jing XJ, Laux D, Lundquist I, Magnuson MA, Obermuller S, Olofsson CS, Salehi A, Wendt A, Klugbauer N, Wollheim CB, Rorsman P, Hofmann F (2003) Impaired insulin secretion and glucose tolerance in $\beta$ cell-selective $\mathrm{Ca}_{\mathrm{v}} 1.2 \mathrm{Ca}^{2+}$ channel null mice. EMBO J 22: 3844-3854.

41. O’Rourke B, Backx PH, Marban E (1992) Phosphorylation-independent modulation of L-type calcium channels by magnesium-nucleotide complexes. Science 257: $245-248$.

42. O'Rourke B (1993) Ion channels as sensors of cellular energy. Mechanisms for modulation by magnesium and nucleotides. Biochem Pharmacol 46: 1103-1112.

43. Yazawa K, Kameyama A, Yasui K, Li JM, Kameyama M (1997) ATP regulates cardiac $\mathrm{Ca}^{2+}$ channel activity via a mechanism independent of protein phosphorylation. Pflugers Arch 433: 557-562.

44. Yokoshiki H, Katsube Y, Sperelakis N (1997) Regulation of $\mathrm{Ca}^{2+}$ channel currents by intracellular ATP in smooth muscle cells of rat mesenteric artery. $\mathrm{Am} \mathrm{J}$ Physiol 272: H814-H819.

45. Yuki T, Yamaoka K, Seyama I (1999) Regulation of 
L- and N-types of $\mathrm{Ca}^{2+}$ channels by intracellular ATP4in frog dorsal root ganglion neurons. Pflugers Arch 438: 117-124.

46. Brunet S, Scheuer T, Klevit R, Catterall WA (2005) Modulation of CaV1.2 channels by $\mathrm{Mg}^{2+}$ acting at an EF-hand motif in the COOH-terminal domain. $J$ Gen Physiol 126: 311-323.

47. MacDonald PE, Sewing S, Wang J, Joseph JW, Smukler SR, Sakellaropoulos G, Wang J, Saleh MC, Chan CB, Tsushima RG, Salapatek AM, Wheeler MB (2002) Inhibition of Kv2.1 voltage-dependent $\mathrm{K}^{+}$channels in pancreatic $\beta$-cells enhances glucose-dependent insulin secretion. J Biol Chem 277: 44938-44945.

48. MacDonald PE, Salapatek AM, Wheeler MB (2002) Glucagon-like peptide-1 receptor activation antagonizes voltage-dependent repolarizing $\mathrm{K}^{+}$currents in $\beta$-cells: a possible glucose-dependent insulinotropic mechanism. Diabetes 51: S443-S447.
49. Dezaki K, Kakei M, Yada T (2007) Ghrelin uses Gai2 and activates voltage-dependent $\mathrm{K}^{+}$channels to attenuate glucose-induced $\mathrm{Ca}^{2+}$ signaling and insulin release in islet $\beta$-cells: novel signal transduction of ghrelin. Diabetes 56: 2319-2327.

50. Satin LS, Smolen PD (1994) Electrical bursting in $\beta$ cells of the pancreatic islets of Langerhans. Endocrine 2: 677-687.

51. Kukuljan M, Goncalves AA, Atwater I (1991) Charybdotoxin-sensitive $\mathrm{K}_{\mathrm{Ca}}$ channel is not involved in glucose-induced electrical activity in pancreatic $\beta$ cells. J Membr Biol 119: 187-195.

52. El-Kholy W, MacDonald PE, Fox JM, Bhattacharjee A, Xue T, Gao X, Zhang Y, Stieber J, Li RA, Tsushima RG, Wheeler MB (2007) Hyperpolarization-activated cyclic nucleotide-gated channels in pancreatic $\beta$-cells. Mol Endocrinol 21: 753-764. 